\title{
Articles
}

\section{Methodologies for Teaching English to Adult Students in Spanish Vocational Education Programs}

Sergio Bernal Castañeda, University of Seville

\section{Abstract}

This paper explores strategies used by teachers of English in Spain to compensate for learning limitations associated with student age. As part of a qualitative study of multiple cases, twenty teachers from different vocational programs volunteered to participate in semi-structured interviews. The interviews revealed the difficulties that older Spanish adult students experience in learning English in age-diverse classrooms. The findings specifically indicate that older adult learners face numerous obstacles in oral comprehension and language production because of the translation and grammatical methodologies with which they were educated. A further obstacle is their younger classmates' linguistic superiority. Special attention is paid to the methodologies used by teachers of

\section{Résumé}

Cet article examine les stratégies utilisées par les enseignants d'anglais en Espagne pour compenser les limitations d'apprentissage associées à l'âge des étudiants. Dans le cadre d'une étude qualitative de plusieurs cas, vingt enseignants de différents programmes de formation professionnelle se sont portés volontaires pour participer à des entrevues semi-structurées. Les entrevues ont révélé les difficultés que les étudiants adultes espagnols plus vieux rencontrent dans leur apprentissage de l'anglais dans des classes avec des étudiants d'âges variés. Les conclusions indiquent de façon claire et détaillée que les apprenants âgés sont confrontés à de nombreux obstacles dans la compréhension orale et la production du langage à cause des méthodes de traduction et de grammaire 
age-diverse groups, including material specificity, real-life practice, repetition and systematization, skill-oriented tasks, and collaborative or cooperative learning. qui ne leur ont jamais été enseignées. Un autre obstacle est la supériorité linguistique de leurs camarades de classe plus jeunes. Une attention particulière est portée aux méthodes utilisées par les enseignants de groupes composés d'étudiants d'âges variés, y compris la spécificité matérielle, les travaux pratiques, la répétition et la systématisation, les tâches axées sur les compétences et l'apprentissage collaboratif ou coopératif.

Keywords: adult learners, age diversity, English learning, L2 skills, vocational studies

\section{Introduction}

As a consequence of a highly pronounced economic crisis and the increasing unemployment rate among adult workers without professional degrees, more Spanish people over 50 years of age decide to return to school to increase their chances of employment. Foreign-language teachers in Spain are increasingly faced with a new and diverse educational scenario in vocational training programs resulting from the wide age range of incoming students. In this article we will analyze this phenomenon and the striking aspects concerning age heterogeneity in vocational training programs, where we find teenagers sitting next to these "new" students who may be double their age. This age diversity involves a new, positive challenge and enriches the environment of the classroom. However, we must consider the learning difficulties experienced by older adult students. In the new Spanish educational system, English instruction is emphasized nowadays. In this context, teachers cope with classes of students with mixed levels of English skills. Students have different sociocultural backgrounds and generational differences, with older adults who are used to traditional teaching methodologies. These older students find themselves alienated and excluded from an educational system that has evolved in new directions during their years of academic inactivity. 


\section{Literature Review}

English teachers working in vocational training programs in Spain have recently witnessed a phenomenon that has taken classroom heterogeneity to a new level. Due to the economic crisis presently affecting Spain, there is a high percentage of unemployed adult professionals between 40 and 50 years old who are returning to school after a long academic hiatus. This trend is fuelled by the need to obtain professional certificates and/or academic and training experience, in order to access the labour market again. According to European Commission data, over $50 \%$ of the Spanish adult population between 45 and 50 years old have not completed senior high school (European Commission, 2015). In addition, because of the reduced number of work contracts that offer acceptable working conditions and benefits and because of the need to compete with the higher qualifications of the upcoming generations who are also targeting these positions, most unemployed adults are also returning to school. According to the European Union, vocational training schools have experienced a never-beforeseen increase in registration rates among older adults, especially in countries affected by the economic crisis, such as Spain (Egetenmeyer \& Nuissl, 2010; Halttunen, Koivisto, \& Billet, 2014; Schmidt-Hertha, Krašovec, \& Formosa, 2014).

This trend has created a new classroom reality in the vocational training programs, where a generational gap may cause difficulties and limitations in the processes of teaching and learning for both teenage and older adult students. ${ }^{1}$ According to vocational teachers, it is no longer rare to find a sixteen-year-old student sharing books in class with an adult close to retirement. This situation enriches the environment of the classroom and creates a diversity that students and teachers can benefit from in cooperative ways (Barkley \& Cross, 2005; Brockett, \& Hiemstra, 1991; Connolly, 2008; Merriam, \& Bierema, 2014). However, teachers have also witnessed serious learning obstacles among adult students who attempt to return to school after decades away. This situation is particularly noticeable in the study of English, which became compulsory in all intermediate and advanced professional training programs through the Organic Law 5/2006 on Vocational Education (Spanish Ministry of Education, 2006) and, most recently, the Royal Decree (Spanish Ministry of Education, 2014b).

Level inequality in the English language classroom affects intermediate and advanced professional training programs differently. For instance, students in intermediate levels come to these programs with their secondary education certificate. Language $2(\mathrm{~L} 2)^{2}$ lessons, in this case English lessons, usually start from a zero position in order to avoid frustration among students with lower levels of English. At the same time, for learners to be successful, they need a basic understanding of the language because the L2 content is presented quickly, in order to cover the basic objectives of the syllabus.

1 In Spain, vocational training programs are offered from age 16, once students have earned their degree in basic education. This means the age mix in the classroom is noticeable since it includes teenagers, young adults, and adults.

2 L2 = second language; $L 1=$ native language 
In the case of the advanced levels, the situation is significantly more complicated. Students can access these programs by completing an assessment test, but the tests do not reflect the high level of English required in vocational studies. There are also students who have obtained their high school diplomas decades ago. For these students, their knowledge of English is usually weak. All access requirements are stipulated by the Government Education Order (Spanish Ministry of Education, 2014a) and are strictly followed by all educational institutions providing vocational studies.

Given the above, adult students with a low L2 level are placed in classrooms with adolescent and younger learners who have recently completed their high school or even postsecondary education where English lessons have been taught up to a level of B1, a mid-range level developed in accordance with the Common European framework of reference for languages (2015. Although not every adult has a lower level of English, our research has shown that with respect to age the majority of adult students demonstrate a lower L2 level than their younger counterparts. This finding coincides with the work of Lenneberg (1967) in "Biological Foundations of Language," where he proposed the existence of a time period or "window" in puberty and adolescence, after which the ideal time for foreign-language acquisition is biologically impossible. This assumption has been accepted by others who specialize in pronunciation and grammar, including Flege ,Yeni-Komshian, and Liu (1999), Käpplinger and Robak (2014), Oh and Kit-Fong Au (2005), and Johnson and Newport (1989).

Traditionally, in the Spanish education system, lesson plans and curricula in schools and colleges have been highly focused on grammar and memorizing of lists of vocabulary and translation from Spanish to English. Little attention has been paid to the communicative approach, L2 oral skills, and the need to transmit, code, and decode messages for real daily comprehension. Lee and VanPatten (2003) and Méndez García (2010) have stated that, due to this excessive attention to theoretical and receptive skills, many adult students have not been sufficiently exposed to foreign languages and have not enjoyed the opportunity of being involved in second acquisition during earlier life stages when language acquisition is optimal (Knowles, 1980; Singleton, 2001; Krashen, 2009). Nowadays, older adult students come from an obsolete and non-practical system and share the classroom with a new generation of learners who have completed their studies in a more L2 communicative way. Additionally, many of the younger students come from bilingual schools.

The renewed Spanish educational system calls for L2 teaching skills that follow the European Framework of Reference for Languages of the Council of Europe. Its scope focuses on the use of methodological strategies centred on oral and written skills that may be initially alien to adult students. Generally, adults experience numerous obstacles in adapting to new methodologies and learning tools, and they tend to create a self-imposed affective barrier, believing that they are not capable of L2 learning at an older age. This attitude stems from the belief that it is impossible to learn new languages at later stages of life (Knowles, 1980; Krashen, 2009). These socially accepted barriers comprise a substantive affective filter and are the most 
important motivational limitation for foreign language acquisition by adult students (Dörnyei, Csizér, \& Németh, 2006; Dornyei, \& Ushioda, 2009; Goetz \& Hall, 2013; Doiz, Lasagabaster, \& Sierra, 2014).

Adult students are generally better and faster learners in lexical or grammatical areas, which are the more theoretical areas that younger students usually dislike. In his work The Modern Practice of Adult Education, Knowles (1980) argued that older adults have more general knowledge and previous experiences in subjects that facilitate better learning. Regardless of this initial advantage, numerous authors (Birdsong, 2006; Oh \& Kit-fong Au, 2005; Smith, 2002) argue that in the long term, younger students will exceed their older adult counterparts and be able to manage all linguistic skills on a native level. They will be especially successful in phonology and pronunciation, the two skills adults usually find most challenging. Adult students have strong phonological habits rooted in their mother tongue and a lack of brain plasticity that prevent them from modifying their pronunciation patterns and acquiring a native knowledge of the $\mathrm{L} 2$.

Theoretically, under the same conditions of input, adult students will become better learn- ers and progress more rapidly than younger students (Krashen, 2009). Ultimately, however, younger students will exceed the linguistic skill of their adult counterparts. The initial success of adults will eventually be halted or fossilized, and the chances of acquiring native- or expertlevel status are reduced. If these theories are considered within the context of age heterogeneity of Spain's vocational programs, young students, who have received input in and exposure to English for at least ten years, are sharing classrooms with older adult learners who face serious limitations. These limitations include a lack of $\mathrm{L} 2$ experience from childhood and an inability to adapt to new learning methodologies because of an absence from academic and other forms of learning during their professional lives (European Commission, 2015).

It is interesting that, in reading and writing, adult students frequently stand out as faster and better learners at the beginning of the linguistic acquisition process (Dekeyser, 2000). However, in the case of oral skills such as listening and speaking, younger students who have been exposed to L2 from childhood demonstrate better understanding of oral comprehension and better production in oral speech (Meisel, 2011; Singleton, 2001). Because of these realities, teachers who work with students at diverse levels and with differences in L2 initial learning need to adapt their teaching methodologies. They must both assist younger learners so that they continue to improve and perfect their linguistic abilities and help adult students understand most of the content experienced in the classroom without getting lost or frustrated (Cook, 2008). For instance, when doing a listening activity in class, teachers may use longer pauses to analyze content and vocabulary, little by little with numerous repetitions. This approach reduces the need to present the activity all at once, without stopping. Furthermore, when teachers use L2 strategies orally in class, they can always do so with breaks in order to provide brief explanations and synonyms in the L2, or equivalents. 
The linguistic superiority of younger students is best understood as separate skills carried out at certain levels of difficulty, depending on the student and previous experience. It follows that older adult students will tend to focus on the skills they feel most comfortable with. Typically, these areas, such as vocabulary, grammar, and morphology, can be analyzed through cognitive processes and learned using memory (Mackey \& Sachs, 2012). At the same time, foreign language acquisition requires real and communicative projection or practice through the oral skills, which is usually the field in which older adults face more limitations. According to Snow and Hoefnagel-Höhle (1978), adult students, aware of their inferiority in oral skills, decide at some point in the learning process to focus on skills in which they feel they have greater proficiency, thus leaving the rest of the communicative competencies behind.

Teachers must convince adult students that they can fully learn a foreign language without achieving native pronunciation. As Meisel (2011), Singleton (2001), and Trofimovich and McDonough (2011) point out, an imperfect accent does not prevent adults from acquiring communicative competence. Neither will it hinder the use of the second language in social and professional spheres. Adult learners also need to understand that learning a foreign language involves acquiring certain skills that enable personal management of the language and culture in real life. Acquiring the fluency of a native speaker or having expert knowledge is not required to be functional in the second-language setting (Nunan, 1998). Students need to understand that real communication is possible without unachievable objectives that lead to frustration and possible dropout. Similarly, educators must focus on certain older groups that, though still being intellectually active, turn out to be part of the so-called "passive" students (Fontanella \& Sandmann, 2011). In short, attention and support from teachers are essential to second-language acquisition among adults.

Due to the increasing importance of foreign-language certifications, L2 learning has become a focus for publishing houses that create textbooks for professional training programs (European Commission, 2015). Nowadays, teachers tend to divide their classes into tasks or activities designed to target one or more English skills. This approach is changing as the learning of English evolves to being taught from a more specialized perspective. Teaching and learning of L2 now include specialized vocabulary relating to areas of study and specialization and tasks based on real situations that students will encounter in future employment. As a result of this shift, publishers who produce language-acquisition materials are developing resources that focus lessons on oral content and the activities of listening and speaking. Grammar and vocabulary are now reinforced rather than being the primary focus. There has been a shift away from long lists of vocabulary and dense grammar lessons to dynamic classes and communicative approaches (Bron, Kurantowicz, Salling, \& West, 2005). Paralleling this methodological shift, systematic-repetition tasks as a means of avoiding L1 interference (Spanish) and helping students without translating have been promoted.

Most teachers regard motivation as one of the most significant aspects of successful adult education (Bialystok, 1997; Birdsong, 2006; Schleppegrell, 2001; Singleton \& Lengyel, 1995). 
Motivation is a complicated element since it is not entirely in the teacher's hands. While self-dedication and an autodidactic attitude are essential factors in establishing and maintaining motivation, unemployed workers with no previous L2 learning or exposure do not normally show initiative in learning on their own.

Older adult students must be also become aware of the usefulness of the knowledge they are acquiring. The applicability of the course content to real life is essential for these students and affects their attitudes towards learning. For this reason, today's new methodologies should work well for them (Boshier, 2006; Egetenmeyer \& Nuissl, 2010; English \& Mayo, 2012; Foley, 2004; Kirkwood, 2012; Leberman, McDonald, \& Doyle, 2006). At the same time, because of interruptions in the learning experience and various neurological factors, adults may experience initial academic shock and other limitations during their studies. Practical content, however, will keep older adult students interested and motivated and will partially compensate for age inequalities.

In the study described in this paper, consideration is given to particular vocational programs in Spain. These programs have recently experienced an increase in older adults in them. Attention is paid to the impact of age heterogeneity on the teaching methodologies used by teachers in L2 contexts and on the strategies used to compensate for limitations in students' oral skills.

\section{Design and Methods}

This paper is based on a project that includes multiple cases (Stake, 2006) and focuses on two different areas. The information obtained through this study illuminates teachers' and students' experiences in intermediate and advanced professional training programs in public and private teaching centres in Spain where L2 learning has recently become compulsory. Twenty teachers from the two program levels volunteered to participate in semi-structured interviews about the difficulties that older Spanish adult students face when learning English.

The participants in this study were professional second-language teachers ( 13 female, 7 male) from student centres in the Seville Aljarafe rural area and western Costa del Sol area in Malaga in southern Spain. All of the teachers were in charge of diverse groups of students from different age and sociocultural backgrounds. All participants were provided official documents prepared by the Department of Research Education at the University of Seville. The documents outlined anonymity and confidentiality protocols. All participants signed the documents.

A non-probability sampling system was used, and demographic information was collected in five areas:

- type of teaching centre

- years of teaching experience 
- age

- geographic area (rural or urban)

- teacher's level of accessibility and volunteerism in relation to students

Each interview included 45 open-ended questions that collected information related to seven categories:

- description of teaching centres

- new trends in andragogy

- age-related diversity

- affective aspects of adult L2 learning

- neurological aspects of adult L2 learning

- L2 learning skills

- teaching methodologies and strategies

Each interview was about 60 minutes in length, with the study occurring over four months, from February to May 2015.

Analysis was built around the following categories:

- previous experience with age-diverse groups

- group characteristics

- affective aspects

- neurological aspects

- teaching strategies

- language skills

Considered together, the categories led to a holistic understanding of the different aspects of adult learning in the L2 classroom.

While the interviews were structured, there were occasions when the conversations strayed from the prepared questions and extended the interview considerably. Even though the number of questions was substantive, many of them were related to others in the same category. Often, a participant would provide the same answer for more than one question.

All the teaching centres in the study offer mandatory and postmandatory study programs, including compulsory secondary education (Spanish ESO), high school education (Spanish bachillerato [baccalaureate]), and intermediate and advanced professional training programs in science and health, or the humanities. The students were from diverse sociocultural, generational, ethnic, and motivational backgrounds. The participating teachers from intermediate studies were from the intermediate professional training programs in management and 
administration, pharmacy and healthcare, secretary studies, and trade and marketing, all established under the guidelines of the Spanish National Educational Agreement (Spanish LOE). These programs include 2,000 training hours, including five weekly hours of $L 2$ or $15 \%$ of the entire workload.

The other teachers in the study worked in advanced groups and were from the advanced professional training programs in administration and finances, dietetics and nutrition, preschool education, and travel agency and events organization. Although advanced programs have a minor L2 workload (four hours weekly), the linguistic content is much more specialized than in intermediate programs. In advanced programs, vocabulary and grammar are more intense, and oral production and comprehension is highly intensified.

After data collection, transcription and analysis of the information were performed through the qualitative analysis data program Atlas.ti. After codification and categorization of the data, including implementation of a system of codes and categories, analysis of the transversality, selection, and dismissal of transcendental and redundant information, and elaboration of categorization and triangulation diagrams, results were interpreted and conclusions were drawn.

\section{Results}

The aim of this research was to gather information about the teaching tools and methodological strategies used by professional language-acquisition teachers to help overcome the obstacles that older Spanish adult students face in learning English as a second language. These obstacles include lack of motivation, loss of linguistic ability in L2, and difficulties in oral comprehension and production skills in age-diverse groups. The findings were reported and divided into two broad areas: suggested L2 teaching methodologies in professional and vocational studies, and adult learners' adaptation to L2 teaching methodologies.

\section{Suggested L2 Teaching Methodologies in Professional and Vocational Studies}

The majority of the teachers identified the importance of one particular strategy used at the beginning of the year when students are enrolling and adjusting to the program: a review of the main grammatical and lexical structures of the L2, emphasizing the most important vocabulary in their field or specialization. The following statement points out the importance of this strategy:

Interviewee 16: One of the best methodological strategies when trying to overcome the initial L2-level gap is to do an intense grammar review during the first two months of the academic year because that is the period of time when students are still enrolling in the program and some might come weeks [after the first day of class]. So what I always try to do is to review everything, in order to balance the class level a little bit and get off to a good start with the syllabus. First, I focus on the parts that students need to reinforce more in order to be able to start fresh with the practical part that comes later on in the year-which is the part that really matters. 
The teachers also emphasized the need to clarify assessment criteria and explain the teaching trends and learning strategies that would be used in the course. Further, students need to understand that it is preferable to work in teams, using collaborative or cooperative learning strategies, critical-thinking skills, and real communicative approaches rather than other strategies. Students must be aware of the different learning tools available to them for mitigating the difficulties of adaptation to new methodologies and, thus, avoid the initial academic shock that some adult students tend to suffer.

Interviewee 8: I think English teachers have completely changed their teaching methodologies in the last 20 years. Nowadays, through the increase of language exchanges with other foreign institutions, the use of new technologies in the classroom, and ICT [information and communication technologies] tools, along with new collaborative learning strategies and critical-thinking skills, there has been a radical change in the way the L2 is taught in class. Adult students must be aware of this development and adjust.

Regardless of the L2 level, older adult students must also be aware of these changes and adjust to them and work collaboratively.

In addition, foreign-language acquisition becomes more accessible when students receive feedback and help from various sources. Teachers need to highlight for students those practices that are most useful in learning the second language: multiple intelligence dynamics (whereby different L2 skills are used), tasks and assignments with clear objectives and real purposes, and real practical models that can help students become involved in their future professional field:

Interviewee 8: Collaborative learning and multiple intelligence dynamics are really important when trying to compensate for the different L2 level in the classroom. For example, a really good technique is the so-called " $1,2,4$," by which students first work individually with personal tasks, and when they are ready, they share their results and impressions with their classmates. Once their findings have been exposed, these two students share the information with other two, creating a 4-classmates team where learning is shared and feedback is better.

Another obstacle at the beginning of the academic year is the fear that adult students have towards L2 content. They usually regard this subject as something distant and strange, something they have not experienced in many years, so they tend to reject it. Also, the fear of looking ridiculous, the shame of talking in public, and a lack of self-esteem can cause group instability. A negative atmosphere as a result of disrespectful or bullying attitudes among students can arise if teachers do not deal with these problems immediately.

Interviewee 2: From the beginning of the year, students' fear of ridicule is a reality, so what I always try to do is to break down barriers in the first sessions when students 
are starting to get to know each other and to try to make them feel confident [when] talking in front of the class. Mocking other classmates is strictly forbidden because our main obstacle in Spain is precisely that, fear of making a fool of ourselves. Once this fear has been overcome, everything will be much better. The first day it is imperative not to laugh at anyone, not to make fun of anybody; whoever knows a lot, good for him or her, whoever knows less has to learn.

The teachers highlighted the importance of helping adult students understand their need to learn English in order to evolve into their future professional roles. Getting excellent academic results should not be the goal. Rather, students must understand and manage themselves in the L2 context so they can master the field in which they will work. The teachers criticized the excessive attention given to academic results not only by adult students but also by educational institutions:

Interviewee 12: It is supposed to be learning by doing; learning by making mistakes, but what they cannot intend to do is to start knowing it all. And this is something adult students fail to understand and then end up frustrated. The important thing is to learn, not to get a good mark. And older adults are too obsessed these days with academic results. As a professional training teacher, I was taught to regard students as people truly wanting to learn, but now they are focusing too much on measuring everyone by competencies. Who knows where this can lead?

Learning by making mistakes was another idea mentioned by most of the teachers. They stressed how important it is for students to understand the importance of learning by making mistakes. Making mistakes is necessary to understanding different language structures.

Positive reinforcement was also identified as another popular teaching method, and the way teachers reward adult students for their achievements is as important as the way they correct and assess them. If the student makes a mistake, the teachers must bear in mind that the way they assess and address the mistake may affect the student in the future. Adults are very self-conscious students and have an exceptionally strong sense of responsibility. Since correcting mistakes can cause tension, it is crucial to help adults see that it is a natural process in learning a foreign language:

Interviewee 6: Another important factor to bear in mind in order not to demotivate students is to be careful with oral, public corrections of mistakes. If the student makes a mistake in front of the class, you can always say: "OK, great, but how would I pronounce that?" That way you can make them see that they made a mistake, without public shame or frustration.

Teachers must avoid the use of a categorical "No!" in their assessment of mistakes. The idea of alternate word choices is important for making the adult student aware of the possibilities for auto-correction and improvement. Teachers may also repeat the same structure but in a different version allowing the learner to notice the mistake in a subtle way. Such approaches decrease the possibility of weakening a person's self-esteem. 
At the other end of the spectrum, positive reinforcement turns out to be fundamental in fostering motivation among students. Rewarding students with positive, cheerful comments when they make a good intervention raises their self-esteem and encourages them to continue participating in class. In all, this approach reinforces motivation and interest in the foreign language.

Interviewee 3: Undoubtedly, the teaching tool I most use is positive reinforcement. [I] tell them all the time, "Come on, you can do it, carry on!"-just to cheer them up [by] emphasizing their accomplishments. I never treat them differently, [older] adults and young students. I assess them in the same way, otherwise it would be discrimination.

Another methodological strategy used in the English classroom is the systematic repetition of particular structures as a way of consolidating their use. The teachers agreed that repeating certain oral structures systematically guarantees steady and long-lasting learning that grammar activities alone cannot provide.

Interviewee 17: There have been numerous opposing arguments against the repetition method, ... whose greatest representative is Vaughan. His technique is based on repeating structures in order to internalize them. So when the student speaks in English, he or she doesn't think about the speech word by word, but rather embraces it as a whole, systematically. It's all about mechanizing and internalizing structures, starting from here.

All the interviewed teachers agreed that it is important not to teach lessons focused on grammar at the expense of practical content. What students are really looking for is training in a particular professional field. The following passage pertains to teachers who are willing to use practical and specialized L2 content that fits the students' needs:

Interviewee 17: In my opinion the practical perspective of the L2 class is indispensable. From the beginning of the year, English has to be used from the professional point of view. Any other way would be a scam for students. They come here to be trained in a particular job or position, and teaching grammar contents or following a textbook once again is nothing but a swindle. They need to know how to greet customers, how to answer the phone properly in different contexts, or write commercial letters, emails, etc. That's what really helps them get a job in the future.

The above teacher used the term "swindle" to refer to traditional methodologies focused solely on grammar. According to the teacher's opinions, what really motivates adult students is training in the particular fields in which they are studying. In Spain, professional training programs include a wide spectrum of subjects.

Teachers in the programs of management and administration, secretary studies, and administration and finances provide students with materials such as commercial letters, company 
emails, complaints, invoices, real accounting entries, bank statements, and so forth. From these materials, teachers can extrapolate the different L2 skills needed for engaging in real life and practical materials in an English setting.

Interviewee 7: Communication and understanding are the real important things here. If they're studying management and administration, why not give them a couple of letters, complaints, or invoices? Things they are really going to [encounter] in the future. Forget about "present continuous."

Lastly, the teachers commented on how individualized teaching and focusing on weak points in order to strengthen the skills that require more attention increase motivation. At the same time, the majority of teachers agreed that individualized teaching was idealistic due to the high number of students in the public school system in Spain. They also agreed that they must provide some individualized follow-up in order to identify students' needs.

Interviewee 11: I think all teachers must be aware of the strong and weak points of their students in an individualized way. It's all about knowing the abilities of each of them and helping them overcome obstacles and acquire competencies.

Ultimately, the intention is not to assess the students in different ways, but to become fully conscious of what they need individually and reward their strongest points. Teachers can reinforce learning with extra work or private tutorials that strengthen the particular skills that adult students find more challenging. This strategy will reduce frustration and guard against high dropout rates.

\section{Adult Learners'Adaptation to L2 Teaching Methodologies}

Adult students generally show difficulty in the production and comprehension of oral speech, identified as speaking and listening respectively (Common European Framework of Reference for Languages). Teachers agree on the importance of students' individual and self-imposed practice. Since these two skills are closely linked, practising outside the classroom is essential. For instance, students can enrol in exchange or tandem programs to practise conversation, use social networks and video-calling programs, or access international websites, in order to keep their speaking skills active. In the same way, English movies, television series, and documentaries are language-learning tools available on every television set in Spain. Now viewers even have the possibility of turning on subtitles in different languages. These activities are excellent opportunities for keeping listening skills fresh, and they are unanimously recommended by the L2 teaching body.

3 "Present continuous" describes an English verb tense and is widely used among English teachers and learners in Spain; it is traditionally taught together with present simple. 
Interviewee 16: The oral skills are considered the most complicated among adult students. I always tell them to practise at home and watch movies in English in order to improve. I tell them that they have this option, and it is important to do so because these skills are the biggest flaws among Spaniards. However, I really don't understand why they don't do it. Years ago, the only chance to practise was [to] buy a cassette and try to guess the lyrics yourself. Now students have a million opportunities, and they waste them.

The teachers argued that it is much more comfortable for older adult students to watch movies or television series dubbed in Spanish because they do not have to make any effort to understand what it is being said or continuously read the subtitles. On the other hand, adults tend to translate all the information they get in their L1 (Spanish). In this sense, there is no exposure to the foreign language, and the possibilities of improving these skills diminish.

Adult students do not benefit as much from English input as their younger counterparts do. The latter are more used to dealing with foreign cultural elements due to their higher use of social networks, the Internet, and English television and radio from early stages of life. What teachers are suggesting is that the less frequent use of these L2 resources by older adults occurs from a lack of habit in participating in social and English language media. They also prefer the comfort and convenience of what is already known (listening in Spanish).

Interviewee 3: The problem of listening is that the adult learner is not capable of understanding it as a whole and frequently gets lost. However, the younger learner is more exposed to $L 2$ on a daily basis. They listen to songs in English [or] watch series and play video games with subtitles, and start recognizing sounds and words that adults just can't. The young people in society are more influenced and globalized in this sense, [and] in contrast to their adult counterparts, this reduces their linguistic learning ability.

The greater exposure to foreign languages by younger learners stands in contrast to the more traditional theoretical and grammatical experiences of the adult learner. In this sense, when the latter must undertake a listening or speaking task, he or she does so from a translation perspective, focusing on the grammar and usually taking the person's L1 as the point of reference. Practising the different skills is not enough and adult students must be taught how to use them. For instance, according to the following interviewee, a student cannot just "study" these kinds of skills during a weekend and expect to be successful as if it were any other kind of theoretical subject. Language learning requires practice, repetition, and time, something that adult learners often lack.

Interviewee 5: The problem is that languages are not like any other subject that you can study for a couple of hours and pass. In L2, the [number] of skills that you need to cope with in order to be communicative requires practice and time. In the skills of 
speaking and listening one cannot just say, "I'll spend the entire afternoon studying" and expect to pass.

The above methodologies could actually be used for all students, not only adults. However, due to the specific limitations of language learning and lack of habit in new methodologies by adult learners, they could benefit to a greater extent if they accepted and adapted to them. Contrary to younger students who are already accustomed to new language-teaching strategies, adults need to adapt to these new learning routines.

In other professional and vocational programs that require much personal contact with customers, such as restoration, tourism, travel agency and event organization, trade and marketing, and preschool education, materials given in class should focus on dealing with clients in courteous ways. Polite and common expressions and vocabulary linked to the particular profession are also required. By comparison, in the case of more scientific-related professional programs such as renewable energies, pharmacy and healthcare, radiology, laboratory technician, mechanics, and the automobile sector, L2 teaching must be oriented to specialized terminology.

Content specificity, communicative approaches, and real-life materials are essential in professional training programs in order to motivate students and make them feel integrated in the classroom. As teachers progressively change their L2 methodologies, adult students must adjust to them in order to learn and use required knowledge in the professional sector. This combination reduces the effect of linguistic and neurological obstacles that naturally affect foreign language acquisition.

\section{Discussion}

Younger learners generally show fewer difficulties in L2 acquisition and assimilate morphosyntactic content and pronunciation better than older learners. This behaviour is in line with the maturational neurological theories espoused by McKay and Wong (1996), Harley (1986), Johnson \& Newport (1989), Oh and Kit-fong Au (2005).

The teachers who participated in this study have defined the basic characteristics of older adult students and differentiate them from those of younger learners. They agreed the older students had

- a greater sense of responsibility, particularly in contrast to the indifferent attitudes toward the future observed in younger students

- a preference for practical teaching strategies

- different motivations for enrolling in L2 programs

- greater difficulty than younger students in managing L2 in public

These observations are supported by Boshier (2006), Foley (2004), Leberman, McDonald, and Doyle (2006), McGrath (2009), and Schleppegrell (2001). 
Vocational training teachers also agree that younger students often display a head start over adults because they began learning the $\mathrm{L} 2$ at an earlier stage of life. This gives them a greater advantage in oral skills, as pointed out in recent research (Oxford, 2003). Both groups share a preference for an inclusive and collaborative environment in the L2 classroom, where they experience solidarity with their classmates and often share a disposition to help each other (Barkley \& Cross, 2005; Brockett \& Hiemstra, 1991; Connolly, 2008; Merriam \& Bierema, 2014).

Adult students often experience numerous learning obstacles with the new L2 learning methodologies that are based on communicative approaches and real practice strategies. Adjustment to this new experience after a lengthy academic hiatus can be arduous and long. Thus, teachers must focus on students' needs and identify the areas in which they lack reinforcement the most (Fontanella \& Sandmann, 2011).

The most problematic skills for adult learners are the ones related to orality. Listening and speaking are the most difficult skills to accomplish for adults who usually do better in writing and comprehension (Dekeyser, 2000). On the other hand, younger learners generally show more fluency in oral skills because of their early preparation in oral work, oriented to real practice and a communicative approach. Adult students must understand that to acquire a communicative level of the foreign language neither a perfect accent nor perfect pronunciation in the L2 is essential for professional purposes (Meisel, 2011; Singleton, 2001; Trofimovich \& McDonough, 2011).

The vocational training teachers selected for this project showed initiative in their methodologies and used current learning strategies and tools. L2 content specificity and transversality, in addition to real application of learning methods through tasks and assignments that students can use in their future fields, were their most useful teaching strategies (Coryell \& Chlup, 2007). Other tools used by these teachers of age-diverse classrooms are repetition and contextualization of oral comprehension and production tasks.

The transition from translation- and grammar-based techniques to a communicative approach is critical for students to understand. L2 learning is becoming more popular in Spain, and lessons and classes are now being taught in more practical, realistic, and dynamic ways than previously (Boshier, 2006; Egetenmeyer \& Nuissl, 2010; English \& Mayo, 2012; Foley, 2004; Kirkwood, 2012; Leberman, McDonald, \& Doyle, 2008; McGrath, 2009).

One question that may arise when considering this new educational reality is why structural changes are not being implemented within the Spanish educational system. This question is especially important in vocational programs in which adult students require opportunities to catch up in areas where they may be academically deficient, such as English language study. Such a shift in the educational system might be possible except for the acute financial crisis that Spain is presently experiencing. Unfortunately, budgetary cuts have doomed the possibility of improvement in foreign language education in recent years. 
Despite the economic and social crises in Spain, it seems logical to support professional training programs that help new types of students. Teachers must take diversity into account not only in terms of ethnicity, religion, and special needs. They must also show diversity in the methodologies they use to advance the learning of adult students who return to school.

Initiative is crucial when learning a foreign language. Obviously, the number of lessons offered in these programs per week is not enough to raise the communicative levels of students so they can succeed in real L2 situations. For this reason, students need to have a personal interest in learning and work to advance by themselves. It is known that older adult students will complete their school hours but refuse to practise outside the classroom. Their motivation to learn a foreign language outside of classes is problematic.

Based on the finding of this study, the teaching methodologies used by $L 2$ teachers have changed remarkably from those of previous years. Traditionally, the foundational pillars when teaching English were grammar, translation, and dependency on the textbook. However, through the internationalization of Spain, exposure to other foreign cultures, and the effects of globalization, these methodologies have evolved to embrace more communicative and practical approaches. Teachers are aware of this change and are choosing to keep up-to-date with new teaching techniques. In short, it is the adult student educated in "the old ways" who faces difficulties in accepting and adapting to new L2 methodologies.

Educators deeply value the effort that older adult students are making to adapt to their new academic lives, and they work hard to raise the hopes and avoid the frustrations of their students. At the same time, teachers wonder what will happen to students over 50 years of age who return to school as a last resort for engaging in the professional world. Most significantly, teachers worry about the excessive rivalry these adults will experience with highly prepared, younger job-seekers.

Unemployed adult students not only face obstacles in the acquisition of new subjects like English. They also feel emotionally and personally detached from a society that has turned its back on them, leaving them professionally and economically inactive. Far from giving up, though, many adults who return to school remain hopeful that education and training will provide them with the necessary skills to take part in the professional work force. In this case, teachers believe that, regardless of the academic frustrations and risks of dropping out, these students can increase their opportunities by drawing on the support of the educational community through new and practical methodologies and within collaborative and cooperative learning environments.

\section{Study Limitations}

One obstacle in this study was access to the participants. The different institutions that offer professional training programs were easy to find through the websites of regional teaching centres and various other educational websites. However, contacting these institutions and their English teachers was a problematic process. Representatives from the majority of 
teaching centres were not interested in participating in any kind of research, while the teachers who did participate had limitations on their availability.

Additionally, there are not many institutions that offer English in both intermediate and advanced professional training programs. This circumstance significantly reduced the sample size. Finally, interviews were long and teachers sometimes could not dedicate as much time as the researchers required.

Future investigations will focus on older adults as the main participants rather than on teachers. Efforts to provide a voice to this group and to understand their point of view will guide this research. Collecting first-hand information about their obstacles in relation to English teaching methodologies and L2 skills is important work and will elucidate the challenges they experience in learning language.

\section{Final Thoughts}

A complete overhaul of our methodology will be necessary if we are to cater to all students' needs relating to age differences. Spanish teachers often complain that neither our educational community nor the new legislation pay no attention to age diversity, which is a new reality (LOMCE: Spanish National Act for the Improvement of Quality in Education). However, both vocational training teachers and adult students are trying to adapt themselves to the needs of the School Linguistic Curriculum and the law regarding evaluation. It is imperative that older students begin to realize the importance of English as an indispensable tool and as a means to graduate and gain access to the work force again. However, this change of mind stems from a more sociocultural sphere that can become a real barrier to language acquisition and may overwhelm any other academic difficulties that older Spanish adult students may face. 


\section{References}

Barkley, E., \& Cross, K. (2005). Collaborative learning techniques: A handbook for college faculty. San Francisco, CA: Jossey-Bass.

Bialystok, E. (1997). The structure of age: In search of barriers to second language acquisition. Second Language Research, 13(2), 116-137.

Birdsong, D. (2006). Age and second language acquisition and processing: A selective overview. Language Learning, 56, 9-49.

Boshier, P. (2006). Perspectives of quality in adult learning. London, United Kingdom: Continuum.

Brockett, R., \& Hiemstra, R. (1991). Self-direction in adult learning: Perspectives on theory, research, and practice. London, United Kingdom: Routledge.

Bron, A., Kurantowicz, E., Salling, H., West, L. (2005). "Old" and "new" worlds of adult learning. Wydawnictwo Naukowe, Dolnośląskiej Szkoły Wyższej Edukacji, Towarzystwa Wiedzy Powszechne. [Scientific Publishing University of Lower Silesia, Common Knowledge Society]. Retrieved from http://www.esrea.org/filarkiv/1.97802/OldandNewworlds.pdf

Connolly, B. (2008). Adult learning in groups. Maidenhead, United Kingdom: Open University Press.

Cook, V. (2008). Second language learning and language teaching. London, United Kingdom: Hodder Education.

Coryell, J. E., \& Chlup, D. T. (2007). Implementing e-learning components with adult English language learners: Vital factors and lessons learned. Computer Assisted Language Learning, 20(3), 263-278. doi: 10.1080/09588220701489333

Dekeyser, R. M. (2000). The robustness of critical period effects in second language acquisition. Studies in Second Language Acquisition, 22, 499-533.

Doiz, A., Lasagabaster, D., \& Sierra, J. M. (2014). Language friction and multilingual policies at higher education: The stakeholders' view. Journal of Multilingual and Multicultural Development (February 2014), 345-360.

Dörnyei, Z., Csizér, K., \& Németh, N. (2006). Motivation, language attitudes and globalisation: A Hungarian perspective. Clevedon, United Kingdom: Multilingual Matters.

Dörnyei, Z., \& Ushioda, E. (2009). Motivation, language identity and the L2 self. Bristol, United Kingdom: Multilingual Matters.

Egetenmeyer, R., \& Nuissl, E. (2010). Teachers and trainers in adult and lifelong learning: Asian and European perspectives. Frankfurt am Main, Germany: Peter Lang.

English, L., \& Mayo, P. (2012). Adult education and the state: Gramsci, the historical materialist tradition and relevant others. European Journal for Research on the Education and Learning of Adults, 3(1), 11-27. doi: 10.3384/rela.2000-7426.rela0050 
European Commission. (2015). Common European framework of reference for languages: Learning, teaching, assessment. Cambridge, United Kingdom: University of Cambridge Press.

Flege, J. E., Yeni-Komshian, G. H., \& Liu, S. (1999). Age constraints on second-language acquisition. Journal of Memory and Language, 41, 78-104.

Foley, Griff. (2004). Dimensions of adult learning: Adult education and training in a global era. Maidenhead, United Kingdom: Open University Press.

Fontanella, P., \& Sandmann, F. (2011). Enseñanza de una lengua extranjera a adultos mayores. [Foreign language teaching to older adults.], Lenguas Modernas, 37, 55-62.

Goetz, T., \& Hall, N. C. (2013). Emotion and achievement in the classroom. In J. A. C. Hattie \& E. M. Anderman (Eds.), International guide to student achievement (pp. 192-195). New York, NY: Routledge.

Halttunen, T., Koivisto, M., Billett, S. (Eds.). (2014). Promoting, assessing, recognizing and certifying lifelong learning: International perspectives and practices. London, United Kingdom: Springer.

Harley, B. (1986). Age in second language acquisition. Clevedon, United Kingdom: Multilingual Matters.

Johnson, J. S., \& Newport, E. L. (1989). Critical period effects in second language learning: The influence of maturational state on the acquisition of English as a second language. Cognitive Psychology, 21, 60-99.

Käpplinger, B., \& Robak, S. (2014). Changing configurations in adult education in transitional times.:International perspectives in different countries. Frankfurt am Main: Peter Lang.

Kirkwood, Adrian (2012). ICT in higher education: Policy perspectives. In ICT Leadership in Higher Education, Conference held 24-26 February 2013, Hyderabad, India, 36-43.

Knowles, M. S. (1980). The modern practice of adult education. From pedagogy to andragogy. New York, NY: Cambridge.

Krashen, S. (1980). Second language acquisition and second language learning. Oxford: Pergamon Press, 152-161.

Leberman, S., McDonald, L., and Doyle S. (2006). The transfer of learning participants' perspectives of adult education and training. Aldershot, United Kingdom: Gower Publishing.

Lee, J and VanPatten, B. (2003). Making communicative language teaching happen (2nd ed.). Columbus, OH: McGraw-Hill Education.

Lenneberg, E. H. (1967). The biological foundations of language: A summary. Hospital Practice, 2, 59-67.

Mackey, A., \& Sachs, R. (2012). Older learners in SLA research: A first look at working memory, feedback, and L2 development. Language Learning, 62, 704-740.

McGrath, S. (2009). Vocational education and training for development: A policy in need of a theory? International Journal of Educational Development, 32(5), 623-631. 
McKay, S. L., \& Wong, S-L. C. (1996). Multiple discourses, multiple identities: Investment and agency in second-language learning among Chinese adolescent immigrant students. Harvard Educational Review, 66, 577-608.

Meisel, J. (2011). First and second language acquisition: Parallels and differences. Cambridge, United Kingdom: Cambridge University Press.

Méndez García, M. (2010). International and intercultural issues in English teaching textbooks: The case of Spain. Intercultural Education, 16(1), 57-68.

Merriam, S., \& Bierema, L. (2014). Adult learning: Linking theory and practice. San Francisco, CA: Jossey Bass. doi: 10.1002/nha3.20125

Nunan, D. (1998). Second language teaching and learning. Cambridge, United Kingdom: Cambridge University Press.

Oh, J., \& Kit-Fong Au, T. (2005). Leaning Spanish as a heritage language: The role of sociocultural background variables. Language, Culture and Curriculum 18(3), 229-41.

Oxford, R. L. (2003). Language learning styles and strategies: An overview. IRAL-International Review of Applied Linguistics in Language Teaching, 41(4). doi:10.1515/iral.2003.012

Schleppegrell, M. J. (2001). Linguistic Features of the Language of Schooling. Linguistics and Education, 12, 431-459.

Schmidt-Hertha, B., Krašovec, S. J., Formosa, M. (Eds.). (2014). Learning across generations in Europe: Contemporary issues in older adult education. Rotterdam, Netherlands: Sense Publishers.

Singleton, D. (2001). Age and second language acquisition. Annual Review of Applied Linguistics. $21,77-89$.

Singleton, D. M., \& Lengyel, Z. (1995). The age factor in second language acquisition: A critical look at the critical period hypothesis. Clevedon, United Kingdom: Multilingual Matters.

Smith, M. K. (2002). Malcolm Knowles, informal adult education, self-direction and andragogy. infed: The encyclopedia of informal education. Retrieved from http://infed.org/mobi /malcolm-knowles-informal-adult-education-self-direction-and-andragogy/

Snow, C., \& Hoefnagel-Höhle, M. (1978). The critical period hypothesis. Evidence from second language learning. Child Development, 49(4), 1114-1128. doi: 10.2307/1128751

Spanish Ministry of Education. (2006). Spanish National Act on Education. BOE.

Spanish Ministry of Education. (2014a). Government Education Order ECD/1030/2014 on Vocational Training Programs. BOE.

Spanish Ministry of Education. (2014b). Royal Decree of Education 1105: Compulsory Secondary Education. BOE.

Stake, R. E. (2006). Case studies. In Norman K. Denzin \& Yvonna S. Lincoln (Eds.) Handbook of qualitative research (pp. 435-453). Thousand Oaks, CA: Sage. 
Trofimovich, P., \& McDonough K. (2011). Applying priming methods to L2 learning, teaching and research insights from psycholinguistics. Amsterdam, Netherlands: John Benjamins.

\section{Biography}

Sergio Bernal Castañeda is a vocational training teacher (English and German) in the region of Andalucía, Spain. He works with groups of adult students who retake their education after becoming unemployed. He is also a PhD student in English education at the University of Seville. Areas of research interest include self-directed learning, age diversity in education, continuing education, and vocational studies. 
JPPCOE Article

JPCOE, Vol 2.1, 2016 